\title{
Van weerloos tot weerbaar: Die Afrikaanse vrouedigter binne patriargale konteks
}

\begin{abstract}
Author:
Lina Spies ${ }^{1}$

Affiliation:

${ }^{1}$ Faculty of Theology,

University of Pretoria,

South Africa

Note:

Prof. Dr Lina Spies is emerita professor in the Department of Afrikaans and Dutch at the University of Stellenbosch. Prof. Spies participated as a research associate in the project 'Biblical Theology and Hermeneutics', directed by Prof. Dr Andries van Aarde, Honorary Professor in the Department of New Testament Studies, Faculty of Theology, University of Pretoria, South Africa.
\end{abstract}

Correspondence to: Lina Spies

Email:

linaspies@xsinet.co.za

Postal address:

PO Box 12262, Die Boord

7613, Stellenbosch,

South Africa

Dates:

Received: 20 June 2014

Accepted: 13 July 2014

Published: 07 Nov. 2014

How to cite this article:

Spies, L., 2014, 'Van

weerloos tot weerbaar:

Die Afrikaanse vrouedigter

binne patriargale konteks',

HTS Teologiese Studies/

Theological Studies 70(1),

Art. \#2771, 13 pages. http://

dx.doi.org/10.4102/hts.

v70i1.2771

\section{Copyright:}

(C) 2014. The Authors.

Licensee: AOSIS

OpenJournals. This work

is licensed under the

Creative Commons

Attribution License.

Read online:

Scan this QR code with your smart phone or mobile device to read online.
Vulnerability to resilience: The Afrikaans woman poet in patriarchal context. On Elisabeth Eybers's poetry and my own. This article gives an account of the nature and content of my religious poems that form a large part of my poetry. Looking back upon my substantial oeuvre, I realise that it was as a woman that I gave expression to the human condition and to my experience of religion. As a woman poet I identified with the first acknowledged Afrikaans woman poet, Elisabeth Eybers. Although a specific female tradition was never identified in the Afrikaans literary criticism, the Afrikaans woman poet writes from within a patriarchal society of which the Bible and Christian doctrine form the basis. This corresponds with the situation of the English and American woman poet. Feministic American literary critics have reflected in depth on the woman poet's dilemma, and have shown that the woman poet's struggle to find her own identity is not against the strong male or female poets who preceded her, but against the inhibiting voices that live within herself. At deepest it amounts to a conflict between fulfilling her traditional female role as prescribed to her by the patriarchy, and fulfilling her vocation as poet - a theme in both Eybers's and my work. Because of the different courses of our lives, the female identities expressed respectively in our work differ: Eybers's identity is that of woman and mother, and later unattached immigrant, while mine is that of an unmarried career woman. In this article I concentrate on the way in which we give expression to our female identities in our poetry as influenced by the traditional Christian belief system in which we were brought up. I give a comprehensive account of the influence of characteristic scriptural language on Eybers's and my own use of words, and I discuss our poems on biblical figures in detail.

\section{Inleiding}

\section{'n Vroulike poësietradisie}

Die bydrae van die vrouedigter tot die Afrikaanse digkuns is nooit as ' $n$ aparte tradisie in die literêre kritiek en geskiedskrywing onderskei van 'n manlike tradisie nie, en het as sodanig ook nie aanleiding gegee tot die identifisering van 'n spesifiek vroulike poëtiese identiteit nie. Mans het dekades lank die terrein van die Afrikaanse letterkunde oorheers. Toe die Afrikaanse letterkunde in omvang en peil ontwikkel het tot die vlak waar dit ' $n$ literatuurgeskiedenis vereis het vir studie in die hoër onderwys, kon dit nie anders as dat mans dit sou skryf nie, want al het die vrou reeds in die 1930's as skeppende skrywer 'n bydrae gelewer, het sy voor die 1950's nog nie as gesaghebbende literator die terrein van die Afrikaanse letterkunde betree nie. Ek verwys hier na twee literatuurgeskiedenisse: G. Dekker se Afrikaanse literatuurgeskiedenis waarvan die eerste druk so vroeg as in 1935 verskyn het en die sesde bygewerkte druk in 1961 (Dekker 1961), asook F.E.J. Malherbe se Afrikaanse lewe en letterkunde van 1958 (Malherbe 1958). In die mees resente en belangrikste twee literatuurgeskiedenisse, naamlik Die Afrikaanse literatuur sedert Sestig (Cloete 1980) waarvan T.T. Cloete die redakteur is en die oorsig oor die poësie sedert Sestig geskryf het, asook J.C. Kannemeyer se Die Afrikaanse literatuur 1652-2004 (Kannemeyer 2005) word die werk van digters sonder geslagtelike onderskeiding bespreek. Soos uit die titel van die tersaaklike literatuurgeskiedenis blyk, konsentreer Cloete op die werk van digters wat in die 1960's gedebuteer het. In sy uitstekende inleiding wys Cloete wel uitdruklik op die religieuse inslag wat my werk met dié van Marlene van Niekerk, Antjie Krog, Ina Rousseau en Sheila Cussons gemeen het, naamlik die 'aanwesigheid van God in die aardse dinge' wat 'n 'religieuse vreugde' word (Cloete 1980:123). Beide Cloete en Kannemeyer wys op die vormende invloed van D.J. Opperman op die jonger digters, veral dié wat sy kreatiewe skryfkursus aan die Universiteit van Stellenbosch gevolg het. In Hoofstuk XX111 onder afdeling V 'Die Stellenbosse impuls en die Letterkundige Laboratorium' bespreek Kannemeyer die bydrae van ses lede van Opperman se sogenaamde Letterkundige Laboratorium uitvoerig: Lina Spies, Fanie Olivier, Leon Strydom, Rika Celliers, Daniel Hugo en Joan Hambidge (Kannemeyer 2005:500-534).

Tereg is digterskap by die bespreking van digters se bydraes tot 'n literêre tradisie die uitgangspunt en nie die digter se geslag nie. By my samestelling uit die werk van Afrikaanse 
vrouedigters, Sy sien webbe roer (Spies 1999), het ek egter dieselfde afleiding gemaak as Maaike Meijer (1988:7) in haar beskouing oor Nederlandse vrouedigters binne 'n manlik georiënteerde literêre geskiedskrywing: 'Wie de dichteressen chronologisch achter elkaar leest ziet een beeld van een traditie, van voortbouwen op elkaar, van thematiese, formele en intertekstuele verwantschappen.' Soos by Meijer kry ons 'n sterk feministiese inslag in die studies van Amerikaanse literatore oor die werk van Amerikaanse en Engelse vrouedigters van die negentiende en twintigste eeu. Hierdie studies het 'n sterk polemiese inslag wat reeds vervat is in die begrip 'vrouedigter', waaruit die implisiete aandrang op erkenning van die eie aard en waarde van die vrouedigter spreek. Die begrip 'poetess' het in Engels tans 'n uitsluitend pejoratiewe betekenis en in Afrikaans het 'digteres' dit ook in hoë mate verkry. Die term 'woman poet' is nie net gebruiklik nie, maar dis ook 'n stellinginname soos blyk uit Paula Bennet se boek Emily Dickinson: Woman poet (Bennet 1990). Dieselfde geld die volgende studies oor vrouedigters: Margaret Homans se Women writers and poetic identity (Homans 1980), Barbara Antonina Clarcke Mossberg se Emily Dickinson: When a writer is a daughter (1982) en Paula Bennet se My life a loaded gun: Dickinson, Plath, Rich, and female creativity (Bennet 1986).

Wanneer die digter ' $\mathrm{n}$ man is, blyk dat in besprekings van sy werk sy geslag irrelevant is en waar kritici nie die klem laat val op die geslag van die vrou as digter nie, kan dit 'n wins wees, maar ook die rede dat belangrike kenmerke van die digter as personasie in die vers misgekyk word. Die eensydige konsentrasie op die vormlike eienskappe van 'n gedig was die resultaat van die 'stiplees-metode'; die 'New Critics' se 'close reading'. Die gedig is vervreem uit sy menslike konteks; die grens tussen die estetiese objek en die lewe het 'n absolute skeidslyn geword. Gelukkig het daar 'n ander ontwikkeling plaasgevind waar die verbintenis tussen die mens agter die teks en die personasie in die teks nie genegeer word nie. Camille Paglia (1992:103) sê hieroor: 'Behind the shifting face of personality, is a hard nugget of self, a genetic gift.' Sy verklaar verder: 'Unlike French post structuralists, I believe there is always a person behind every text' (Paglia 1992:115). Daar is natuurlik gevare daaraan verbonde om erns te maak met die mens agter die teks, omdat biografiese besonderhede daartoe kan lei dat dit in 'n teks ingelees word, terwyl dit nie daarin staan nie. Andersyds kan eensydige konsentrasie op die vormlike eienskappe lei tot ' $n$ verskraling van dit waaraan die digter uitdrukking wil gee, hetsy 'n ervaring, 'n gedagte, 'n emosie of wat ook al. In haar seminale studie, Afstand en verbintenis (Jansen 1996) oor die bundels van Eybers se Nederlandse periode, maak Ena Jansen erns met die mens Eybers as immigrant. Dit lei haar tot ' $n$ insiggewende bespreking oor die invloed van die Nederlandse taal en lewensfeer op Eybers se poësie. Sy demonstreer deur interpretasie van gedigte dat onkunde oor Eybers se Nederlandse leefwêreld vir die Afrikaanstalige leser die sin van 'n gedig kan ondermyn. Wanneer die lewenswerklikhede van die mens agter die teks kenbaar is in die teks moet dit verdiskonteer word om aan die eise van 'n adekwate interpretasie te voldoen.
Om oor my eie religieuse verse te skryf moes ek 'n spesifieke invalshoek vind. Ek het dit gekry by Elisabeth Eybers wat my belangrikste en bekendste voorganger is. Ons albei is Bybelsgevormde digters en opgevoed binne ' $n$ samelewing met 'n Christelike en Bybelse grondslag. Ook is ons albei grootgemaak binne 'n gesin van drie dogters - sy die tweede oudste en ek die oudste - sonder vroulike stereotipering, maar ons moes ons nogtans los skryf van die groter patriargale tradisie, want wat Margaret Homans (1980:29) van die negentiende-eeuse Engelse en Amerikaanse tradisies sê, geld ook in hoë mate van die Afrikaanse tradisie in die twintigste eeu: 'The JudaeoChristian tradition is notoriously misogynistic.' Sonder om Eybers se werk te stereotipeer as 'tipies vroulik', sien ek dit as die begin van 'n vroulike poësietradisie in Afrikaans waarby ek kon aansluit met poësie van eie individuele aard.

\section{Elisabeth Eybers, die eerste vrouedigter: Identifikasie met Bybelse vroue en 'n gepredestineerde digterskap}

Die eerste erkende Afrikaanse vrouedigter, Elisabeth Eybers, debuteer in 1936 met Belydenis in die skemering en in 1939 volg Die stil avontuur. Sy kry onmiddellik erkenning vir haar werk en ontvang die Hertzogprys vir haar eerste twee bundels. In teenstelling met vroeëre Afrikaanse digters (Celliers, Totius, Leipoldt) se stereotiepe, verheerlikende siening van die vrou (spesifiek die Afrikanervrou binne volksverband) teken Eybers die vrou vanuit haar wesensaard. In Belydenis in die skemering bely die jong meisie haar bewussyn van ontwakende vroulikheid en romantiese liefde. In Die stil avontuur beleef die jong moeder die stil avontuur van swangerskap en geboorte, in Die vrou en ander verse (1945) stel die vrou haar as bewaarder van die lewe vyandig op teen die dood as vernietiger en in Die ander dors (1946) is Eybers se ek-spreker by herhaling die vrou wat, ondanks liefde en moederskap, onvervuldheid beleef as onvervreembaar deel van die menslike kondisie.

By die kritici was daar van die begin af hoë waardering vir Eybers se vroulike visie en vir haar treffende poëtiese verwoording daarvan. Die iets denigrerends in die titel van D.J. Opperman se hoofstuk 'Elisabeth Eybers: Die vroulike aanvulling' in sy gepubliseerde doktorale proefskrif, Digters van Dertig, moet dus nie buite perspektief beskou word nie. Die eerste druk verskyn in 1953 voor die hoogty van vrouestudies en feministiese literatuurkritiek. Sy vertrekpunt in sy bespreking van Eybers se bydrae stel hy pertinent aan die orde:

Die Afrikaanse letterkunde was baie lank hoofsaaklik 'n letterkunde van die man se siening van die lewe ... Eers met die Dertigers - daardie geslag by wie ons reeds so 'n groot verskeidenheid en gehalte van werk aantref - kry ons die vroulike aanvulling in ons letterkunde: in die poësie met Elisabeth Eybers en in die prosa met Hettie Smit. (Opperman 1962:351) 
Opperman (1962:359) waardeer die weerbaarheid van Eybers se belydenis van vroulikheid in haar debuut, veral omdat dit 'uiters selde' gekenmerk word deur 'weekheid of sagmoedigheid'. By Die vrou en ander verse vestig hy wel die aandag op die gevaar in die herhaling van die grondgedagte van die bundel:

In haar gedigte oor die vrou as ewige voortbrengster oorheers die moeder-kind-tema weer. 'n Sekere eendersheid vind ons dikwels in die poësie van digteresse, veral van digtende moeders; maar by hierdie natuurlike eendersheid het daar ook 'n bewuste eendersheid gekom: Elisabeth Eybers het in die Afrikaanse poësie haar eie rigting gevind en begin uitbuit. (Opperman 1962:370)

By die waardering vir Eybers se intensiewe ontginning van vrouwees is dit jammer dat waar Opperman tereg wys op die gevaar van eendersheid in die werk van vrouedigters, hy geringskattend verwys na 'digtende moeders'. Waar moederskap, soos enigiets wat behoort tot die menslike kondisie, uitdrukking vind in gedigte, word die waarde daarvan bepaal deur die mate waarin die vrouedigter die adekwate poëtiese uitdrukking daarvoor gevind het.

Elisabeth Eybers se kindertyd en jeug het 'n sterk vormende invloed op haar digterskap uitgeoefen. Op die Wes-Transvaalse dorpie Schweizer-Reneke, waar haar vader predikant was van die Nederduitse Gereformeerde kerk, groei sy op binne 'n Calvinistiese sfeer en 'aanvaar hierdie lewenshouding' (Opperman 1962:358). Ná hierdie beskermende plattelandse pastoriejeug gaan studeer sy aan die Universiteit van die Witwatersrand en maak kennis met onverskilligheid teenoor die godsdiens, agnostisisme en Freud wat, volgens Opperman (1962:360), lei 'tot 'n gespanne soeke na helderheid en na God' en na 'belangwekkende verse' in Belydenis in die skemering. Daarvan bespreek hy kortliks drie: 'Genesing', 'Die dromer' en 'Bede'. 'n Mens kan slegs die afleiding maak dat die belang van die verse vir Opperman gelê het in die geestelike soeke, momenteel ook na God, wat daaruit spreek, want die verwoording geskied in retoriese taal. Hy lees die gedig 'Volmaan' as voorbeeld van Eybers se ervaring van die 'onverskilligheid' van God waarop haar 'tipies vroulike soeke' na Hom uitloop as sy Hom nie vind as 'n 'simpatieke Wese in die heelal' nie (Opperman 1962:360). Die soeke na God verdwyn uit haar debuut om nie weer in haar poësie terug te keer nie.

Waarin Eybers se religieuse belangstelling behoue bly, is in haar portrettering van Bybelse vroue wat natuurlike aansluiting vind by haar poësie as uitdrukking van tipiese vroulike ervaring. In Belydenis in die skemering teken sy die portrette van twee Nuwe Testamentiese vroue, Maria, die moeder van Jesus in 'n gedig wat haar naam dra en die vrou wat aan bloeding gely het en deur Jesus genees is in die sonnet 'Toe het my hoop ...'. Die verhaal van die genesing van die vrou wat aan bloedvloeiing gely het, word deur al drie evangeliste van die sinoptiese evangelies vertel, maar die uitvoerigste deur Markus (Mark 5:28-34) en Eybers volg hom nougeset na. Slegs hy haal aan wat die vrou gedink het: 'As ek maar sy klere kan aanraak, sal ek gesond word'
(Mark 5:28). Sy is Eybers se ek-spreker en vertel die verhaal uit haar perspektief. Soos in die Bybel is die vrou anoniem en so ook Jesus na wie net as hy en hom verwys word. Die vrou, gewoond om volgens die Wet as onrein beskou te word weens haar onophoudelike bloeding, wil ongekend verdwyn, maar Jesus se vraag na wie hom aangeraak het, hef haar anonimiteit op, gee haar vroulike waardigheid aan haar terug. Eybers lê haar die vraag na Jesus se goddelikheid wel in die mond, maar sy menslikheid oorheers, en Eybers sien die geneesde vrou as verlief op Jesus (Operman 1962:360):

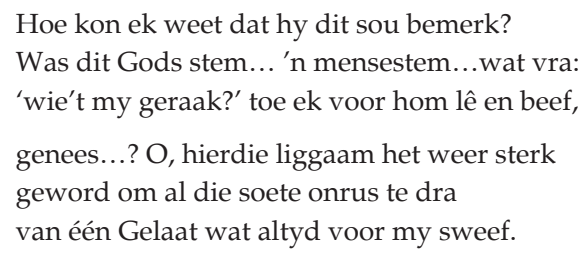

Uit haar gedig 'Maria' spreek Eybers se intense meelewing met die moeder van Jesus. Sy bevraagteken die 'vreugdeboodskap' waaroor Maria in strofe 1 'n 'lofsang tot Gods eer sing' in die gedig deur elke ervaring van Maria se swangerskap en vroegste ervaring van moederskap te vergelyk met 'n ervaring van Jesus tydens sy kruisweg tot en met sy kruisiging. Deur die kontras wat aan die grond van skynbaar ooreenkomstige pynlike ervarings lê in die 2de tot die 6de strofe word die 'nooi uit Nasaret' van strofe 1 die 'vrou van smarte' in strofe 7. Die gedig konsentreer Bybelgetrou op Jesus, maar is ten diepste 'n gedig oor die smart van Maria en, deur haar, van alle moedersmart. Daarom eindig die gedig ook nie by die 'Man van Smarte' nie, maar by sy moeder:

\section{Toe dit verby was en jy met sy vriend Johannes huis toe gaan - \\ Maria, vrou van smarte, het \\ jy tóé die boodskap goed verstaan?}

'Maria' is 'n voorbeeld van hoe Eybers haar subjektiwiteit as vrouedigter kon transendeer en in 'n gestaltevers aan 'n meerdimensionele vroulikheid uitdrukking kon gee. Die ander dors bevat meerdere gedigte wat as 'gestalteverse' van die intiem persoonlike gedigte onderskei kan word. Eybers se blywende belangstelling in Bybelfigure vind in haar bundel Die ander dors neerslag in die gedig 'Hagar'. Deur verwerping en deur die minderwaardigheid wat die kulturele sfeer waarbinne sy moes leef, aan haar opdring, word Hagar die prototipe van die vrou met die ongeleste 'ander dors' (Gen 21:9-21). Die weekheid in die eerste strofe van die sonnet verwys na hoe Hagar in die woestyn gehuil het uit vrees dat sy en haar seun van dors sou sterf nadat sy op Sara se instigasie deur Abraham weggejaag is. God het haar egter ' $n$ fontein aangewys en in die slottersine word haar vroulike weerloosheid omgekeer in manlike weerbaarheid. Sy word haar seun, Ismael, die sterk, kragdadige woestynmens, die derde persoon wat haar lewe aangeraak het:

Die derde is jy: my eensaamheid, my pyn, word weerbaar en verstrak in die woestyn tot ' $\mathrm{n}$ man se bitter trots, 'n man se haat. 
In teenstelling met dié sterk gestaltevers hou die gedig 'Maria Magdalena' met as subtitel 'uit wie sewe duiwels uitgegaan het' verband met die intiem persoonlike sonnette waarmee die bundel open en is kennelik die 'objective correlative' vir eie gelede pyn. Waar in die gedig 'Toe het my hoop ...' die 'Gelaat' van Jesus altyd 'sweef' voor die vrou wat deur hom genees is, kan Maria Magdalena 'geen woorde vir die wonder kry':

as dat Jy my met helderheid omhul

soos lig en lug en dat Jou stilte my

met soetheid soos ' $n$ boom met sap vervul.

Ondanks die hoofletters is Jesus hier weer die geliefde - of die metafoor vir hom - en vervul Hy dieselfde rol as vir die vrou wat Hy van bloeding genees het: Hy maak vir Maria Magdalena 'n nuwe lewe moontlik. Sy staan aan die 'teer begin' daarvan, en sal die 'doel en sin' van wat daaraan voorafgegaan het, nog peil met die wete dat dit die einde was van 'alle bitterheid en pyn', die 'neerlê van die laaste las'. Ook die gedig 'Adam en Eva' is die 'objective correlative' vir ' $n$ menslike liefdesverhaal waarin die man en vrou besef dat vir die paradyslike geluk wat hulle deur God ontneem is, vergoed word deur die ontwaakte bewussyn van hulle seksuele verbondenheid aan mekaar:
Eers toe die neerlaag en die nuwe leed
die dwase vreugde uit hul oë wis
het hul mekaar aanskou, het sy geweet
hoe sterk die man, en hy hoe skoon sy is.
Verbanne bondgenote teen die lot:
sy arms om haar was 'n vaste kring
en selfs die toorn en die wraak van God
kon nie deur daardie tere vesting dring.

Met die publikasie van Die ander dors het Eybers die eerste fase van haar digterskap afgesluit. Sy het vroulike identiteit haar eie gemaak en verse geskryf oor vrouwees waarvan sommige subliem is in hul suiwerheid van woord en vastheid van vorm. Nogtans het sy 'n beperkte wêreld beheers wat Opperman (1962) in essensie saamvat:

' $n$ Mens is selde in Elisabeth Eybers se poësie bewus van die 'heelal' of 'n ander 'wysheid' as dié van die vrou. Haar poësie speel hom af binne huishoudelike dimensies en betrekkings: die verhouding tussen vrou en man, tussen moeder en kind en tussen die vrou en haar ego. (bl. 376)

Eybers het ongetwyfeld ingesien dat om verder uit 'n eensydige, vroulike perspektief te skryf 'n doodloopstraat kon word en met die titel van haar volgende dun bundeltjie, Tussensang (1950), die verwagting van 'n vernuwing in vooruitsig gestel.

Die verwagting het glansend in vervulling gegaan in die daaropvolgende bundel, Die helder halfjaar (1956). Die bundel verteenwoordig ' $n$ tematiese verruiming van Eybers se poësie en 'n radikale vernuwing van haar taalgebruik. Sonder dat 'n manlike tradisie in die Afrikaanse poësie geïdentifiseer is, het dit bestaan. Afrikaanse kritici was tot en met ongeveer die 1970's uitsluitend mans. By waardering vir haar tematiese vernuwing deur in die Afrikaanse poësie stem te gee aan die vrou, is Eybers nie heeltemal ten onregte nie gekritiseer vir haar neiging tot bewerende en abstrakte taalgebruik deur onder andere P. du P. Grobler en A.P. Grové. Die wese van die tematiese verruiming in Die helder halfjaar het gelê in ' $\mathrm{n}$ meer dimensionele vroulikheid wat waardeer is, nie op sigself nie, maar om die uitdrukking daarvan in sterk beeldende taal.

Die verhoogde kreatiwiteit van Eybers met die aanbreek van haar middeljare het tot gevolg gehad dat sy afstand kon neem van haarself en haar vrouwees en kon leer ironies lewe en skrywe. In 'Op die kruin', die tweede gedig in die bundel, is die spreker, 'n selfrefleksiewe $j y$, bewus van die verlies van spesifiek vroulike attribute wat met die middeljare gepaard gaan, maar terselfdertyd ook van haar hernieude kreatiwiteit. Sy staan letterlik en figuurlik 'op die kruin'; letterlik het sy 'n 'steilte' uitgeklim van waar sy afkyk op die stad en figuurlik staan sy op 'n 'klein Ararat', want soos Noag het sy 'n 'vloed' oorleef; die tradisionele vroulike rol het sy knelgreep losgelaat en sy kan haar 'onderbroke spel/opnuut hervat in son en wind'. Die spel wat eie is aan die kind kan sy voortsit as die 'edel spel' van die poësie ('Behoud' in die bundel Neerslag). Deur die stadsgewoel in terme van seebeelde te beskryf, suggereer Eybers die vloedverhaal en illustreer sy hoe sy die taal van die Bybel metafories kan aanwend vir 'n persoonlike ervaring.

In die Bybel vind sy ook die metafore om in die sublieme gedig, 'Musiek', uitdrukking te gee aan die betekenis wat die musiek as kunsvorm vir die liefhebbers daarvan het. Sy praat namens 'n anonieme 'ons', maar impliseer haarself as digter - en ander digters - as een van die 'ons' deur vergelyking van die musiek met die poësie om die musiek eindelik as die hoër kunsvorm te beskou:

Musiek, subtiele liggaamlose taal, ontsmet ons van die aardse onheil, haal ons heelhuids op uit die geslote kring van tyd en ruimte. Engele het gesing lank voor die vroegste woordewisseling, die skraal veewagtertjie moes telkens weer met siterspel die bose gees besweer en bo die dampe van die laaste puin sal slegs ' $n$ enkele jubelende basuin die magte van die duisternis ontwrig, die chaos suiwer soos deur vuur en vloed.

Dan skrompel die deursigtigste gedig tot perkament bevuil met mensebloed.

Musiek het by uitnemendheid die vermoë tot transendensie; lig die luisteraar tot in ' $n$ dimensie buite tyd en ruimte waarbinne hy ingesluit is. Die woord besit nie, soos die musiek, net helende en suiwerende krag nie soos blyk uit Eybers se aktivering van ' $n$ dubbele betekenis, positief en negatief, in 'woordewisseling'. Deur die gawe van taal aan die mens kon die eerste mensepaar in hul paradyslike onskuld 'woorde' met mekaar 'wissel', maar ná die oortreding van God se gebod, volg hulle 'woordewisseling' voor God oor wie se skuld dit is. Engele sing, mense 'twis'. Die Bybelse verhaal van Dawid wat Saul met sy siterspel 
kalmeer, gebruik Eybers as beeld vir die musiek wat ons geesteskwellinge 'besweer'. En die reinigende krag van die musiek wat ons van 'aardse onheil' 'ontsmet', sal aan die einde van die 'tyd' die 'chaos' 'suiwer'. Deur die woord 'perkament' te gebruik vir die besmette papier wat al is wat sal oorbly van 'n gedig, suggereer Eybers ons eeue lange aardse bestaan as mense met 'n gekwelde, maar ook skeppende gees. Die musiek was daar voor die skepping van die aarde en sal daar wees ná die vernietiging daarvan.

Binne die konteks van die bundel verras 'n gedig wat weer eens 'n Bybelse vrouefiguur aan die woord stel en weer vir die digter as 'objective correlative' dien. Die gedig 'Ná dertig jaar' gaan oor die opwekking uit die dood van die dogtertjie van Jaïrus wat deur drie evangeliste - Markus, Matteus en Lukas - vertel word. Haar opwekking het plaasgevind nadat Jesus onderweg na haar eers die vrou wat aan bloeding gely het, genees het. Deur dié oponthoud het Hy by sy bestemming aangekom toe die dogtertjie reeds dood was, maar die omstanders verseker dat sy net slaap en haar beveel om op te staan: 'Dogtertjie, Ek sê vir jou, staan op! En die dogtertjie het dadelik opgestaan en begin rond loop, want sy was twaalf jaar oud ...' (Mark 5: 41, 42).

Die buitengewone ontmoetings van twee vroue met Jesus gebeur direk ná mekaar, waarskynlik binne enkele ure, en al drie evangeliste vertel die twee gebeurtenisse in dieselfde hoofstuk. Op Eybers het dié twee ontmoetings kennelik 'n diep indruk gemaak, al gee sy lank ná mekaar daaraan poëtiese uitdrukking. Die ooreenkoms tussen die twee verse lê daarin dat die vrou wat van bloeding genees is, en die dogtertjie van Jaïrus as volwasse vrou, Jesus as minnaar onthou. Die eertydse dogtertjie voel haar op twee-en-veertig nie aan die hede verbonde nie, maar smag terug na Jesus om ' $n$ teenoorgestelde wonder te verrig en haar vir altyd te laat slaap, want 'geen bevel het ooit so teer/'n kind se warm slaap versteur'. In die laaste drie strofes van 'Ná dertig jaar' spreek sy dié verlange uit:

\footnotetext{
Nou is dit seker lank genoeg

dat sy orent en wakker is

sou Hy nie sê 'my kind, gaan rus'

as Hy kon weet sy is so moeg?

As sy die trae pyn vertel

waarvan haar hart tot barstens bot,

hoe sal Sy mond se sagte spot

haar praat aandagtig vergesel,

as sy Hom vind, as sy Hom weer

herken ... Sy lê die halwe nag

starogig, styf, en fluister sag,

sag en verdwaas: Wanneer, wanneer?
}

Ná Die helder halfjaar verskyn Neerslag in 1958, 'n bundel wat die hoë standaard van sy voorganger handhaaf. 'n Nuwe tema in die bundel is die rekenskap wat Eybers self gee van haar verhouding met haar ouers en van die eienskappe wat sy van hulle geërf het. Uit hierdie latere verse blyk dat Eybers nie, soos Opperman beweer het, haar maklik en sonder wroeging losgemaak het van haar godsdienstige opvoeding nie, maar uiteraard was sy bewering gegrond op haar Dertigerpoësie en kon hy die aard en inhoud van haar toekomstige poësie nie voorspel nie:

Dit is opvallend dat die lewensbeskouing van die pastorie waarin Elisabeth Eybers grootgeword het, feitlik geen regstreekse uiting in haar poësie vind nie. Dit is asof sy sonder veel moeite en opstand daarvan afskeid geneem het ... asof sy geen orgaan vir die 'religieuse soeke' besit nie. (Opperman 1962:374)

Geen 'orgaan vir die religieuse soeke' waaroor Opperman wel gelyk gehad het, beteken nie geen opstand teen die godsdiens nie. Elisabeth Eybers se pastoriejeug het wel 'n skadukant gehad. In die sonnet 'Terugblik' kom sy fel in opstand teen die voorbestemmingsleer van Calvyn wat haar snags 'soms tot beswymens bang' laat voortstrompel het na 'vrystad' van haar moeder se bed. Die moeder het die 'vroegste flits van agterdog' 'laat skyn' 'op die gehurkte garingbuik, Calvyn,/wat waghou oor sy wrede web'. Die dominee-vader se flits gooi, in teenstelling, nie in die gedig 'Vader' 'n helder ligbaan nie. Hy was haar wandelmaat as kind wanneer daar 'geen enkel lig in ons klein dorp meer brand' en sy 'vaste hand' het haar 'teen elke wankeling bewaar'. In plaas van wedersydse vertroue het daar egter wedersydse onbegrip tussen die vader en sy volwasse dogter ontstaan:

Vandat my vingers sy vertroude vuis ontglip het, bly hy onbegrypend staan en prik sy flits se flou en lukraak baan die donker wat ek sorgeloos deurkruis.

Die slotwoord van die gedig 'deurkruis' assosieer die Calvinisme met 'n dogma wat die mens met kwellinge daarvan weerhou om jouself uit te leef; jy moet die eie ek, inteendeel, kruisig. Haar siening van die Calvinisme in 'Terugblik' en 'Vader' bevestig Eybers deur wat sy van Uys Krige sê in 'n artikel, 'Individualisme in die Afrikaanse liriek' wat oorspronklik verskyn het in Die Brandwag van 20 Maart 1937 en opgeneem is in Eybers se bundel kritiese opstelle Voetpad van verkenning wat Kannemeyer (1978) saamgestel het:

Uys Krige is die eerste Afrikaanse digter by wie daar geen spoor van die Calvinistiese lewenshouding te bespeur is nie. Sy sinnelikheid is met geen skuldbesef gemeng nie; hy weet van geen kruisiging van die vlees ter wille van die gees nie; sy oorgawe aan die aardse en verganklike ken geen voorwaardes of beperkings nie (bl. 20, [my kursivering])

Ondanks haar agnostisisme inspireer die beroemde 'Pietà', die beeld van Michelangelo in die Sint-Petruskerk in Rome van die moeder van Jesus met sy liggaam op haar skoot, Elisabeth Eybers tot haar sonnet 'Pietà' in Neerslag. Watter gevoelige kunsliefhebber sou in elk geval onverskillig kon staan teenoor dié grootse voorstelling van Maria, wat volgens Rooms-Katolieke tradisie, die gestorwe Jesus na sy kruisiging kon vashou? En Eybers wou immers 'eendag 'n vroulike Michelangelo word!' (Opperman 1962:353). Eybers se 'Pietà' voer binne haar oeuvre 'n gesprek met 'Maria', maar anders as in die vroeë gedig bly Eybers se spreker op die agtergrond, al is haar ontroerde stem hoorbaar in haar 
beskrywing van die beeld. Sy beskryf die gesig van Maria as 'jonk en verwonderd' wat klop met haar vergoddeliking waarvolgens sy gesien word as deur die tyd onaangetas. In die vier slotreëls van haar gedig skryf Eybers teen dié vergoddeliking in deur haar vermenslikte siening van Jesus wat sy verder dryf as wat haar Protestantse agtergrond haar streng gesproke veroorloof. Die woord 'makkers' het betekenisnuanses van familiariteit; van gemeensaamheid wat nie eie was aan die verhouding tussen Jesus as leermeester en sy dissipels nie:
$\mathrm{Al}$ het geen ander vrou hom ooit vervreem
word alle seuns uithuisig op die duur.
Sy makkers sal hom uit haar skoot kom neem,
soos vroeër ook, maar nou's dit nog háár uur.

In Neerslag is daar meerdere suiwer gestalteverse soos 'Job' as beeld van uiterste menslike lyding waar 'Gods hand' alles uitgewis het en Job in die loop van 'n 'ganse dag' 'ineengekrimp' het 'tot 'n klein pit van pyn'. Volgens haar siening van die Calvinisme is God vir Eybers die wrede beskikker van die mens se lot:

\section{Weerskant wink neonseine langs die straat; \\ as die verkeerslig wip van geel na groen \\ wys God Sy ondeurgrondelike gelaat \\ en, werend opgehef, Sy wit handskoen. \\ ('Keerpunt')}

By die bespreking van die gedigte in Neerslag is dit opvallend dat Kannemeyer in sy literatuurgeskiedenis glad nie melding maak van Eybers se opstand teen die Calvinisme wat duidelik spreek uit 'Terugblik' en 'Vader' nie; hy bring dit eenvoudig in verband met ander verse oor familie en die kind: "n Hele aantal verse in Neerslag handel oor die ouers ("Vader" en "Terugblik") en die verhouding tot die familie en kind' (Kannemeyer 2005:174). Kannemeyer (2005:174) volstaan met een kort sin oor die kwatryne in die bundel: 'Die kwatryne in Neerslag mis oor die algemeen die kernagtigheid van dié van Opperman.' Dit ontgaan hom dat die kwatryn 'Keerpunt' ook 'n beeld is van God wat ooreenstem met Eybers se beeld van Hom in 'Terugblik': die skrikbeeld van 'n God wat onverbiddelik oor die mens se lot beskik. Kannemeyer se kommentaar oorbrug nie die afstand tussen die spreker in dié verse en die leser nie deurdat die persoon van die spreker, die mens agter die teks, geïgnoreer word.

Eybers se emigrasie na Nederland het haar poësie uiteraard indringend beïnvloed. Waar dit vir my gaan om Eybers as vrouedigter, is haar wending weg van 'n eng vroulike tematiek versterk deurdat die ervarings van die immigrant nou voorop gestaan het in haar lewe. Die menslike dimensie van haar poësie is daardeur verruim. Die sterk gesekulariseerde Nederlandse samelewing waarbinne sy haar bevind het, was waarskynlik ook aanleiding tot die verdwyning van uitgesproke versetsgedigte teen Calvyn en die Calvinisme in haar poësie. Wat gebly het, is die invloed van die taal van die Bybel op die taal van haar verse en verse oor Bybelfigure. In Onderdak (1968) kom sy tuis in die nuwe land en in 'n nuwe liefde. Sy beleef dit as 'n opstanding uit die dood soos Lasarus toe Jesus hom uit die dood opgewek het in die elfde hoofstuk van die Johannes-evangelie; die eerste twee strofes lui:

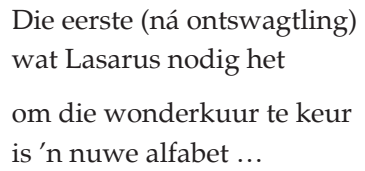

Eybers se beeld van God as die onverbiddelike God van Calvyn is kennelik gevorm deur die dogma waarmee sy noodwendig deur 'verpligte kerkgang' ('Opvoeding' in Rymdwang) grootgeword het, ondanks wat Opperman (1962:352) oor haar vader dr. John Eybers sê, naamlik dat hy die evangelie 'sonder sterk beklemtonings van die dogmatiese' verkondig het. Daar was by Eybers geen aandrang om vas te stel of God nie ook anders verstaan kan word nie en wat dit betref, was Opperman (1962:374) reg met sy veronderstelling dat sy 'geen orgaan vir die religieuse soeke' gehad het nie. Wat vanaf haar middelperiode, ingelui deur Neerslag, nie weer uit haar werk verdwyn het nie, behalwe in haar laaste twee ouderdomsbundels, is herinneringsgedigte oor haar ouers. Sy sou deur hulle genetiese erfenis aan haar 'van onversoenbaarhede' 'later nooit genees' sê sy in 'Oorsig' in Balans. Haar teenstrydige aard sou 'n blywende impuls bly vir verse oor haar ouers, maar ook vir haar poësie in die algemeen:

\section{Met aftreksels van skaduwee \\ moet ek my daagliks voed: \\ my vader was die dominee, \\ my moeder vlees en bloed.}

In dié gedig verwys sy ook na die moeder se 'stiletskerp gees', maar anders as sy, het haar dogter, die 'erfkind' van haar 'week hart en wakker gees' ('Terugblik'), nie 'gevit' en 'gevra' nie. Eybers het die sin van die lewe gevind in liefde en poësie. 'n Geding met God was wesensvreemd aan haar en die enigste konflik wat sy ten opsigte van die godsdiens ervaar het, was hoe om die leerstellinge waaraan haar vader geglo het met sy persoon en met haar agnostisisme te versoen. 'Die enkel taak', die inleidende gedig van Onderdak, is 'n poging om hierdie versoening te bewerkstellig. Die aanvangsreël van strofe 2 verwys na haar vader se enkelvoudige toewyding aan sy lewenstaak: 'Jy het gestol binne die enkel taak.' Dié taak word in die slotreël gekwalifiseer as die 'enkel eis van God en mens te dien'. Die insig waartoe sy kom, is dat sy soos haar vader 'n 'soort suiwerheid' dien; 'n 'wreder molog van die woord'.

In die $\mathrm{Ou}$ Testament word dikwels van die afgod Molog melding gemaak. Dit was 'n gruwel in die oë van God dat sekere Israeliete van hulle kinders aan Molog geoffer het (Lev 20:2-5). As Eybers sê dat sy 'n 'wreder molog dien, verwys sy na die God van Calvyn wat sy as wreed beskou (vgl. 'Vader' in Neerslag) en wat by implikasie ook die God van haar vader was. Sy vra haar in die derde strofe af hoe hy 
sy toewyding aan God en sy naaste kon uitleef sonder dat dit in botsing gekom het met die dogma wat hy aangehang het:

Hoe het jy dit gebolwerk met jou teer

hart en die harde stellings van jou leer?

Die woord 'gebolwerk' suggereer dat haar vader sy geloof teen enige moontlike twyfel of aanslag verskans het. Dit is opvallend hoe in die Afrikaanse literêre kritiek nie net die mens agter die boek bewus genegeer is nie, maar ook hoe die bespreking van digters se werk toegespits is op hul bemoeienis met die aard van die poësie in die gedig self. Die sogenaamde 'digterskapsgedig' het in die sentrum van die aandag gestaan. 'n Groot getal verse uit veral Neerslag en Onderdak het hulle uitstekend geleen om as 'digterskapsgedigte' geïnterpreteer te word, myns insiens beslis nie altyd ten regte nie. In my kort studie oor Eybers, Die enkel taak, bespreek ek die verse in die bundel Onderdak wat deur meerdere kritici as 'liefdesverklarings aan die poësie' gelees is in besonderhede om uit te wys dat hulle van die mees erotiese verse in Afrikaans is. Eybers se verhouding tot die beoefening van die poësie as kunsvorm is ook veel komplekser as 'n enkelvoudige liefde vir die woord. Soos die erotiese liefde is ook Eybers se godsdiensbeskouing in die bespreking van haar latere werk op die agtergrond geskuif. T.T. Cloete wy sy opstel 'Die tuiste in die vers' soos uit die titel blyk aan 'n bespreking van Eybers se 'digterskapsgedigte'. Hy bring die sentrale idee van die gedig 'Die enkel taak', nl. die spanninge waarmee die verwantskap van die ongelowige dogter met haar geliefde domineevader gepaardgegaan het, glad nie ter sprake nie. Sy hele bespreking baseer Cloete (1970:41) op sy eerste stelling: 'Reeds in Die enkel taak, die eerste gedig van die bundel, word alles op die poësie en sy eise betrek.' Vir Eybers is die skeppende woord van uiterste belang maar in 'Die enkel taak' hou dié belang verband met die verhouding tussen vader en dogter wat Cloete heeltemal buite rekening laat. Eybers se soeke na wat vader en dogter gebind het, ondanks hulle vervreemding, vind sy daarin dat soos sy staan onder gesag van die kuns van die woord, haar vader gestaan het onder die gesag van die verkondiging van die Woord van God. Die uiteindelike oplossing vir die spanning vind sy in hulle gedeelde liefde vir die Afrikaanse woord. In 'Dank' (Dryfsand) dank sy hom naas sy 'ontoeganklikheid/ vir alles wat nie strook met wat jy glo' vir sy 'skoon, skerp woordeskat uit die Karoo'.

Sy kan uiteindelik vrede maak met Calvyn se voorbeskikkingsleer deur sowel haar digterskap as die skryfakte waardeur die gedig ontstaan as gepredestineerd te beskou. Reeds met die titel van haar veertiende bundel Rymdwang gee sy te kenne dat sy onder dwang van die rym staan. As literêr-teoretiese term het 'rymdwang' 'n negatiewe betekenis as ' $n$ ongeoorloofde manipulasie van die taal deur die digter om woorde te laat rym. Deur 'rym' gelyk te stel aan die maak van 'n gedig ontdoen Eybers die digterskap van die verheerlikende assosiasies daaraan verbonde. Die gedig is gepredestineer om op 'n bepaalde wyse vorm te gee aan wat die digter wil sê; hy is nie 'n heerser oor die woord nie, maar 'n dienaar van die woord. In die titelgedig 'Rymdwang' blyk die dwang om te dig onmoontlik om te negeer:

Jy kan daar wel of nie op ag slaan maar

kies mettertyd om keuse te laat vaar.

Die gepredestineerdheid van die gedig is die tema van die speels ironiese gedig 'Opvoeding' waar gedwonge kerkbesoek nie die vroeë aanloop tot geloof was nie, maar tot poësie:

Verpligte kerkgang het my toegerus met blywende afdwalende gedagtes.

Gevolg: dat alles waarvan ek bewus word eie wette volg en dat verwagtings en gissings wat ek moes verdring as kind later 'n paslike onderkome vind.

Sy gee in 'Miskien', in verband met die predestinasieleer, ook toe dat die Calviniste wat sy ironies 'allesweters' noem, dalk gelyk het en dat sy God tog aan die ander kant sal ontmoet. Maar haar voorstelling van dié ontmoeting is lig ironies: Sy loop haar as 't ware trompop vas in God. Haar denkbeeld van God is nie in die dogmatiese en rasionele gegrond nie, maar in die twee dinge wat sin gee aan haar lewe en wat vir haar 'n sekere transendensie moontlik maak:

Die saaiste deugde wat jy kan bedink

uithouvermoë, selfontsegging - blyk

ten slotte dwingend, kan nie meer ontwyk

word wanneer elke tinteling versink.

Onwrikbare voorbeskikking kom straks uit, die allesweters wis tóg, sal jy sien

sodra jou sin en sintuie faal. Miskien

is dit God self waarop jy eindelik stuit:

die hiëroglief vir alles wat begrip

en definisie uittart en ontglip.

Maar wat vir jou aan hierdie denkbeeld raak het met liefde en musiek te maak.

Eybers het tot aan die einde van haar lewe agnosties gebly en terselfdertyd verbonde aan die woord. In die inleidende gedig, 'Opsomming' van Valreep/Stirrup-cup (2005) - die laaste van haar vier tweetalige bundels en van haar oeuvre - 'benader sy die einde van haar baan' met die wete dat sy 'verduur' het wat sy 'geprogrammeer/was om van die aanvang te deurstaan'. Die uitspraak suggereer 'n seker geloof in voorbeskikking, maar word deur Eybers se kenmerkende ironie van 'n swaarwigtige assosiasie ontneem. Haar enigste hoop is om tot aan die einde haar 'woordvernuf' ('Woordeloos' in Bestand) te behou. Die 'skroothoop nietighede' wat sy agterlaat, maak dit vir haar moontlik 'om sonder omkyk te verkas,/met rym - indien moontlik - steeds in 'n verfraaiende rol.'

Die gedig wat Eybers se siening van haarself as vrou en haar houding teenoor die godsdiens konkreet en in essensie weergee en my hele betoog kernagtig saamvat, is 'In die domkerk' (Neerslag): 
'n Somber vrou omhels die smal biegkraam

selfkruisigend op soek na sielerus

en bo haar hoof brand, heerlik, ongeblus

ná driekwartduisend jaar, die kleureraam.

Vergeef my onbegrip, ook ek is vrou

en glo die kunstenaar, nie die priester, het

iets uit die paradys vir my gered:

elkeen bly aan haar eie nood getrou.

\section{'n Ekskursie in eie werk: Die ontdekking van metafore en die God van die aarde}

Terugskouend op my digterskap en spesifiek op my religieuse verse, moet ek soos Eybers by my ouerhuis begin. My vader het as hartstogtelike poësieliefhebber herhaaldelik vir sy drie dogters gedigte van vroeë Afrikaanse digters en ook van Engelse digters voorgelees en aan ons ' $n$ blywende liefde vir die poësie gegee. Ons is verder opgevoed binne die hoofstroomgodsdiens van die Afrikaner, die Calvinisme, soos dit verkondig is binne die Nederduitse Gereformeerde kerk. Gereelde bywoning van die erediens en huisgodsdiens het vanselfsprekend daarby gehoort. By huisgodsdiens het hy sonder persoonlike voorkeure 'n kort maar samehangende stuk uit die Bybel voorgelees. Beginnende by Genesis wou hy die Bybel letterlik tot by Openbaring deurlees. Ek het dus as kind ook die $\mathrm{Ou}$ Testament grondig leer ken. In die godsdienstige opvoeding van sy kinders was my vader sterk formalisties. Ons het nie oor ons geloof, die godsdiens of dogma gepraat nie. Aan die opregtheid van my ouers se geloof het ek nooit getwyfel nie. Uit hulle geloof het hulle kennelik krag geput en daarin die beginsels gevind waarvolgens hulle wou lewe. Ek het eenvoudig aanvaar dat ek soos hulle 'n gelowige Christen was.

Anders as Elisabeth Eybers aan die Engelstalige Universiteit van die Witwatersrand het ek aan die Universiteit van Stellenbosch binne die veilige omgewing van Afrikaans, Afrikanerskap en die daarmee gepaardgaande Christelike geloofstradisie gebly. Ek is wel gekonfronteer met 'n ander geloofsbelewenis as waaraan ek tuis gewoond was. Die studentelewe het 'n opsigtelike vroomheidsaanskyn gehad, onder andere deur die CSV (Christelike Studente Vereniging) waarvan byna almal, ek inkluis, lid was. Binne die sfeer van die weeklikse kringbyeenkomste waartydens 'n Bybelgedeelte gelees en gebid is, het ek nooit werklik tuis gevoel nie. Die wyse waarop medestudente voortdurend gepraat het oor hulle geloof en veral die aandrang dat ons moes 'getuig vir Jesus' het my pynlik ongemaklik gemaak. Die Skriflesing en gebed by die aandetes het 'n toenemende irritasie geword toe ek in my derde jaar saam met my medehuiskomiteelede, die prinsipale en die inwonende verpleegster elke aand aan dieselfde tafel moes eet. Dit het neerslag gevind in my gedig 'Koshuis-aandete' in my debuutbundel Digby Vergenoeg (1971), die eerste uitdrukking van die verset wat in my begin smeul het teen die konvensionele geloofsbeoefening:
Ons sing 'Op berge en in dale',

Simonsberg is donspienk in die laaste strale.

Ons lees 'een Konings, hoofstuk negentien',

'Heer, dankie vir die kos wat ons nie verdien.'

'Nog 'n stukkie vis? Pas op net vir 'n graat.'

$\mathrm{O}$, die platane is groen langs Victoriastraat!

Ek gee vir jou die brood en botter aan.

'Ons bid vir die siel wat hoër as die liggaam gaan.'

Die tafeldoek tussen ons is leeg en wit.

Hoe lank, o Here, moet ek nog hier sit?

Mens moet van die besembos na Horeb gaan

om in die sagte stilte te kan staan.

Jy moet jou brood eet en jou water drink,

êrens weer die pad terug na Elisa vind.

Die invloed van my drie jaar studie in die Filosofie is vir my kenbaar in die gedig. Filosofie was my hoofvak, naas Afrikaans en Nederlands, en vir drie jaar het ek die verryking en bevryding ervaar wat die denke van Johan Degenaar moontlik gemaak het. Van totale vergeesteliking het hy die godsdiens teruggebring na 'n vreugdevolle liggaamlike bestaan op die aarde en ' $n$ ware medemenslike ontmoeting met jou medemens as 'n 'ander ek'. 'Koshuis-aandete' gee uitdrukking aan presies die teenoorgestelde van die blydskap om saam te kan eet en te gesels. Die voeding van die siel geniet voorrang bo die voeding van die liggaam, en die ete word gekenmerk deur formele beleefdheid eerder as gesellige samesyn. In dié gedig kontrasteer ek die abstrakte met die konkrete: dodelike geroetineerdheid binnenshuis met stuwende lewe buitenshuis. Die gedig kon geëindig het by die 'leë wit tafeldoek' in strofe 5 wat dui op 'n afstandelike verhouding tussen mens en mens.

Die sesde en sewende strofe waarmee die gedig wel eindig, het as subteks 1 Konings 19 wat die verwysing daarna as die gelese Skrifgedeelte in strofe 2 nie toevallig maak nie. Elia wou in dié hoofstuk sy werk as profeet aflê toe hy in moedeloosheid onder ' $n$ besembos in die woestyn gelê het, maar is daar deur 'n engel beveel om te eet en te drink, en daarna na berg Horeb te gaan waar hy die opdrag van God ontvang het om Elisa as profeet in sy plek te salf. Elia was as profeet te groot, en sy ontmoeting met Elisa te buitengewoon, om vir my meer te word as 'n metafoor vir die mens wat in opdrag van God op weg gaan om 'n medemens as naaste te ontmoet.

Soos uit my gedetailleerde bespreking van 'Koshuis-aandete' blyk, het die taal van die Bybel soos by Eybers in meerdere van my verse neerslag gevind. Ons is albei Bybelsgevormde digters, maar anders as sy het ek nie met my pa in konflik gekom oor die dogma van dieselfde kerk as dié een waarvan haar vader predikant was nie. Die predestinasieleer van Calvyn het ek van jongs af as onregverdig beskou, maar dit het nooit 'n gespreksonderwerp tussen my en my pa geword nie. Ek het dit eenvoudig verwerp en my eie geloofspad gevolg, wat maklik was in 'n gesin waar nie oor die Bybel, die geloof of die dogma gediskusseer is nie. My pa het nie onkrities gestaan teenoor die prediking 
nie en het preke dikwels ongunstig beoordeel, veral oor die predikant se onpresiese woordgebruik, maar nooit na buite nie. Hy het lewenslank 'n getroue lidmaat van die Nederduits Gereformeerde kerk gebly en moes noodwendig die prediking aanvaar het wat uitgaan van 'n letterlike verstaan van die Bybel, weens die oorgrote meerderheid van kerkgangers se onvermoë om metafore as die uitdrukking van waarhede omtrent God en Christus te verstaan.

Die omgekeerde het met my gebeur. Johan Degenaar het 'n passie vir die poësie gehad en buite die formele kurrikulum om het hy poëtiese reëls in die klas aangehaal wat my aangegryp en 'n leeftyd lank as digter geïnspireer het. Sulke verruklike reëls het gekom uit Gilbert K. Chesterton (1961) se hoofstuk 'The ethics of elfland' in sy Orthodoxy, onder andere oor 'n God wat anders as 'n volwassene nooit moeg en verveeld raak nie:

For grown up people are not strong enough to exult in monotony. But perhaps God is strong enough to exult in monotony ... It may be that He has the eternal appetite of infancy; for we have sinned and grown old, and our father is younger than we. (bl. 59)

Diep onder die indruk van Degenaar se lesings en die daarmee gepaardgaande meevallers soos die aanhaling uit Chesterton, het ek nie eens besef dat ek besig was om te leer dat mens nie anders oor God kan praat as deur metafore nie. In my derde jaar het D.J. Opperman die pos aanvaar as professor in die Afrikaanse letterkunde aan die Universiteit van Stellenbosch en het ek deelnemer geword aan sy kreatiewe skryfkursus; 'n lid van sy sogenaamde Letterkundige Laboratorium en het hy my die mag van die metafoor as literêre uitdrukkingsmiddel leer ken.

Ek is deur mans gevorm as mens en digter: deur my pa, Johan Degenaar en deur my vaderdigter, Opperman. Vir al drie 'vaders' het ek groot toegeneentheid en liefde gehad en koester ek lewenslange dankbaarheid. Die standpunt van die invloedryke Amerikaanse literator, Harold Bloom, oor die gespanne verhouding tussen die jong digter en sy literêre voorgangers het uitdrukking gevind in, onder andere, sy bekende werk The anxiety of influence. Dit het ook groot aanhang in die Afrikaanse literêre kritiek verkry, maar nie by my aanklank gevind nie, omdat literêre 'vadermoord' nooit vir my 'n opsie was nie. Ek het wel daarvan kennis geneem deur vroulike kritici wat voorbehoude daaroor het, soos byvoorbeeld Paula Bennet (1986), soos blyk uit haar volgende stelling:

In the oedipal conflict between the poet father and the poet son, which Harold Bloom has elaborated in a series of books, the roots of the male poet's struggle for self-definition and selfempowerment have, presumably, been laid bare. And many feminist scholars have argued, so have the origins of the woman poet's ambiguous and difficult relationship to both the literary tradition and her own creative drives. (bl. 10)

Volgens Bennet is die literêre tradisie en groot voorgangers egter slegs van relatiewe betekenis vir die vrouedigter in haar worsteling om haar eie stem te vind. Op die vraag waarmee sy dan wel in konflik is, antwoord Bennet (1986):
The woman writer's principal antagonists are not the strong male and female poets who may have preceded her within the tradition, but the inhibiting voices which live within herself. The chief source of her anxiety is not that she will be insufficiently distinguished from her literary predecessors, but in fulfilling her destination as a poet, she will be forced to hurt or fail those whom she loves - whether they be mother, father, husband, lover, friends, or children - and thus bring society's opprobrium upon herself. Her struggles are, in short, not literary, but part of life. It is to her life, therefore, that we must turn to understand the process by which she comes both to define and to accept herself as woman and poet. (bl.10)

Dit is ongetwyfeld van toepassing op Eybers en ook op, onder meer, Antjie Krog, en ongetwyfeld op my. Ek het nie 'n stryd gevoer teen voorgangers nie, maar my hoogstens probeer losmaak van die stem van Eybers sodat ek kon voorkom dat sy - om Van Wyk Louw aan te haal - in my 'woordklank mee sou praat'. Dit het onder andere beteken dat ek bewus daarteen gewaak het om soos die vroeë Eybers in my taalgebruik te neig na bewering. Ook is ek daarvan bewaar om 'n epigoon van Eybers te word deurdat ons lewens verskillend verloop het. Ná die publikasie van my debuutbundel Digby Vergenoeg in 1971 en my aanstelling in 1972 as dosent aan die Universiteit van Stellenbosch in die afdeling van die Afrikaanse letterkunde, waarvan Opperman hoof was, het ek die pad van die geëmansipeerde, ongetroude vrou begin loop. Op dié pad was geen ommekeer moontlik nie.

My lewenservarings as ongetroude, kinderlose vrou was wesenlik anders as Eybers s'n as getroude vrou en moeder, en later ná haar egskeiding as alleenstaande vrou en immigrant. Wat ons werk wel gemeen het, is die worstelinge met ons vrouwees in 'n manlik georiënteerde en godsdienstig gefundeerde samelewing. Die metafore vir die ervaring van die ongetroude vrou se kinderloosheid het ek in die drieluik wat my debuutbundel inlui, gehaal uit my Nederlandse leefwêreld as student aan die Vrije Universiteit van Amsterdam. Die eerste gedig van dié drieluik 'Drie laelandse verse vir die nie-ontvangene nooit geborende 'Met liefde' lui:

Ek kan jou geslag kies

en die kleur van jou oë

sonder smeekbede aan 'n opperwese

Ek kan vir jou 'n naam gee

wat vir my mooi is

sonder kwelling oor 'n ouma se voorkeure

Ek kan vir jou 'n Makkum-bord

bestel uit Friesland

met dié naam daarop geverf

en dit hang teen die muur

van my verbeelding,

Droomkind

Ek hoef my nooit te erger aan 'n snotneusie nie: die geboortedatum op die mooi blou bord meld die jaar nul.

Bybelsgevormdheid het ek as digter met Eybers gemeen. Waar sy haar as vrou met Nuwe-Testamentiese vroue identifiseer, 
is dit opvallend dat die eerste Bybelse vrou waarmee ek my in my debuut vereenselwig, die Ou-Testamentiese Migal, die vrou van Dawid, is. Dit hang ongetwyfeld saam met my ongetroude staat en kinderloosheid. Ek was my pynlik bewus daarvan dat binne kulturele Afrikaner-konteks die ongetroude staat van die vrou ná 'n sekere ouderdom die aanleiding kan wees tot haar stereotipering as die tipiese 'oujongnooi'; 'n woord wat nog steeds in woordeboeke opgeneem word sonder die voorbehoud 'beledigend' in hakies daarna (Eng.: 'derogatory'; vgl. HAT en ANNA). My gedig, 'Migal aan Dawid' in Digby Vergenoeg, neem die vorm aan van 'n gesprek waaruit 'n vrou se verset spreek om deur 'n man soos 'n objek behandel te word. Koning Saul het sy dogter Migal as 't ware van een man na die ander aangegee.

Dawid se verwerping van Migal - die kern van my gedig - is deel van die verhaal van sy terugbring van die ark van die Here na Jerusalem waar dit ontvang is met 'gejuig en basuingeklank' en Dawid net met 'n linneskouerkleed aan gehuppel en gedans het voor die aangesig van die Here. Toe Migal dit deur 'n venster sien, het sy hom verag (2 Sam 6:15-16). By sy tuiskoms met die bedoeling om sy huisgesin te seën, tree sy as vrou op ongeoorloofde wyse teenoor hom as man op deur hom van onwaardige gedrag te beskuldig. Uiteraard gaan my gedig terug na die $\mathrm{Ou}$ Afrikaanse Bybelvertaling, maar ek haal die woorde wat Migal Dawid toevoeg liefs uit die jongste Nederlandse vertaling aan omrede van die sarkasme wat daaruit spreek en haar minagting duideliker te kenne gee: 'De koning van Israël heeft zich vandaag bijzonder waardig gedragen! Als de eerste de beste dwaas heeft hij zich voor zijn slavinnen en onderdanen ontbloot!' (2 Sam 6:20). Uit Dawid se antwoord blyk sy hoogmoed as hy haar daarop wys dat God hom bo haar vader as koning verkies het en dat as sy hom nie hoog ag nie, hy nog by die slavinne, van wie sy minagtend praat, hoog in aansien sal staan, selfs as hy hom in sy eie oë verneder.

Die verhaal eindig met die stelling dat Migal tot die dag van haar dood geen kind gehad het nie. Die status van die vrou in Israel het saamgehang met die baar van kinders vir haar man. Kinderloosheid is gesien as straf van God wat die vrou van aansien in die oë van die samelewing beroof het. My gedig oor Migal is geïnspireer deurdat ek die vrouehaat in die verhaal van Migal kennelik raakgelees het. Migal sien in my gedig haar kinderloosheid as melaatsheid waarvan net Dawid se liefde haar kan genees as hy na haar sou terugkom as minnaar, al sal hulle seksuele gemeenskap nie haar kinderloosheid ophef nie.

Wat Elisabeth Eybers vir vrouedigters ná haar gedoen het, is om die taboe op die seksuele intimiteit as deel van 'n liefdesverhouding op te hef. Ten diepste was dit ook die opheffing van 'n godsdienstige taboe. ' $n$ Liefdesverhouding was die deurlopende tema van my tweede bundel Winterhawe wat in 1973 slegs twee jaar ná Digby Vergenoeg verskyn het. Die aardse liefde het kennelik 'n demper geplaas op my godsdienstige belangstelling en eers weer 'n impuls geword vir die godsdienstige verse, wat naas die familieskapverse, die grootste komponent van Dagreis (1976) uitmaak. Die meeste van die religieuse verse in die bundel het gegaan oor my ontmoeting met die Jesus van die kerygma; die Jesus soos hy in die kerk verkondig word: die redder wat ons vryspreek ('Vryspraak'), die trooster ('Maaltyd'), die ondeurgrondelike van wie elke gelowige 'n verskillende beeld het ( 'Onverklaarbare'). Ek sou nog 'n lang reis aflê op die ongekaarte pad van die geloof na die historiese Jesus, maar in my gedig 'Curriculum Vitae' het ek vir die eerste keer met Jesus, die Jood, in gesprek getree:

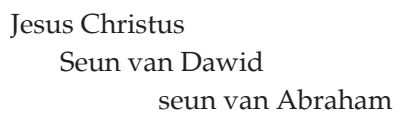

kind van Nasaret, onderdanige klein Hasid, 'n lok langs elke wang

wat jy wegskud in jou spel,

swart keppeltjie op jou kop,

wapper-fraiings aan jou klere,

hoekklossie - teken van die uitverkorenes.

Jy sing zemirots op die sjabbat,

saam met jou vader die lof van Jahwé.

Hy dra die lang bidsjaal van die getroude

as hy langs jou in die sinagoge staan

want hy is Josef van Maria,

die vrou uit wie jy gebore is.

Op Simgat Tora dans jy

met' $n$ wetsrol in die hand

en jy huil op Joom Kippoer

oor elke pogrom, elke razzia -

jongman van drie en dertig,

aan-die-kruishout-oopgevlekte-goy, Koning van die Jode,

roepend na Ribono Sjel Olàm: 'Eloï, Eloï ...'

Die sjofar dreun sy donker oor Jerusalem.

Beide T.T. Cloete en J.C. Kannemeyer verwys in hulle bespreking van Dagreis in die tersaaklike literatuurgeskiedenisse net kortliks na hierdie gedig en kyk die interne spanning, die spil waarom die gedig wentel, mis en maak ook nie erns met die Hebreeuse woorde nie. Die interne kontras is vervat in die verwysing na Jesus enersyds as 'n Hasid en andersyds as 'n goy. As Hasid word Hy erken as vrome Jood volgens 'n agtiendeeeuse beweging in Oos-Europa wat 'n meer spontane geloofsbelewenis voorgestaan het in opposisie teen die rabbynse beklemtoning van formele studie van die Tora (Rosten 1976:73-74). Daarenteen verwys ek ook na Jesus as goy dit wil sê 'n 'Gentile' wat óf slegs as 'n neutrale, onderskeidende benaming vir 'n nie-Jood óf pejoratief gebruik kan word (Rosten 1976:143-144). Dit kom neer op twee opposisionele sienings van Jesus uit Joodse perspektief. 'Simgat Tora' is ' $\mathrm{n}$ vreugdevolle fees nadat die eerste vyf boeke van Moses deurgelees is en die voorlesing daarvan weer op die Sabbat 'n aanvang neem (Rosten 1976:390). 'Joom Kippoer' is die 'Groot Versoendag'; in die sinagoge 'n diens van kollektiewe skuldbelydenis (Rosten 1976:455-458). Uit Hebreeus vertaal, beteken 'Ribono Sjel Olam' 'Master of the world' (Rosten 1976:311). Cloete (1980:244) sê dat naas die gedig 'Fontein' oor die 'heilsgeskiedenis', 'Curriculum Vitae' verwys na die 'donkerte van Christus se eie lewe'. 
Kannemeyer (2005:509) vat my siening van Jesus in dié gedig in een sin saam: 'In "Curriculum Vitae" sien sy Christus agtereenvolgens as kind, jong man, gelowige Jood en uiteindelik die gekruisigde.' Wat die gedig eintlik sê, is dat tussen sy geboorte en dood Jesus se volledige 'Curriculum Vitae' as Jood beskryf is, met verwysing na sy pyn as Hy sou geweet het hoe hy as rede vir die vervolging van sy eie mense gebruik is. Van skrywers van literatuurgeskiedenisse kan hoogstens verwag word om sleutelgedigte in bundels indringend te bespreek, maar die miskyk van die opsigtelike Joodwees van Jesus in 'Curriculum Vitae' het daartoe gelei dat die gedig ook nie herken is as 'n groeipunt in my oeuvre nie. Cloete se beskouing van my werk was beperk tot my eerste drie bundels; Kannemeyer het in sy beskouing die vyf bundels wat ná Dagreis verskyn het, ingesluit. Dit is wel so dat soos Opperman nie in sy bespreking van Eybers as Dertiger haar latere opstand teen die Calvinisme kon voorsien nie, in die besonder Cloete, maar ook Kannemeyer, nie die volle konsekwensies van my siening van Jesus se Joodwees in Tydelose gety (2010), my tiende bundel, en in nog ongepubliseerde verse, vooruit kon sien nie.

My belangstelling in die Joodsheid van Jesus was in eerste instansie die natuurlike gevolg daarvan dat ek vanaf my Vrystaatse jeug op Harrismith Jode geken het. Hulle was 'n geïntegreerde deel van die samelewing en op hoërskool deel van ons Afrikaanse leerlinge se kollektiewe identiteit. My kennisname aan die universiteit van die Holocaust en die gruweldade van die Nazi's deur die rapportering van die Eichmann-verhoor in 1961 in Die Burger, het saamgeval met my lees van Anne Frank se dagboek, Het Achterhuis. Dit het die impuls geword vir die eerste gedig van my wat Opperman in sy geheel goedgekeur het sodat ek glo dat 'Vir Anne Frank van Het Achterhuis' die vertrekpunt was vir my ernstige beoefening van die digkuns. Die naaste wat die Holocaust aan my gekom het, was toe ek in my Amsterdamse studietyd by 'n Joodse vrou ingewoon het wat Auschwitz oorleef het. Dit het so na aan my gekom dat my geloof as Christen langsamerhand 'geloof ná Auschwitz' geword het. Die eerste impuls daarvan was my gedig 'Curriculum Vitae' waarvoor ek die nodige begrippe uit die Judaïsme kon haal deur die lees van Chaim Potok se romans The Chosen en My name is Asher Lev. Veral belangrik vir my digterskap was dat ek ná my uittrede as professor die dagboek van Anne Frank in Afrikaans vertaal het en my kon verdiep in die teologie wat 'teologie ná Auschwitz' geword het.

My bewussyn van die Holocaust het nou saamgehang met 'n hernieude belangstelling in die Ou Testament. Ek het in 1984 lid geword van die kommissie vir die herberyming van die psalms en nou saamgewerk met Ou-Testamentici wat my op hoogte moes bring van die oorspronklike Hebreeuse teks. Ek het nie net die outentisiteit van die psalms leer besef nie, maar van die Ou Testament in sy geheel. My nuwe waardering van die Ou Testament as 'n boek oor die aarde en menslike mense in hul verhouding tot ' $n$ Verbondsgod, wat tegelykertyd transendent en immanent is (in 'n dimensie bo hul lewens verhewe én in hul lewens aanwesig), was 'n uitbreiding van wat ek by Johan Degenaar geleer het. Ek het my sesde bundel
Hiermaals aan hom opgedra met as motto 'n aanhaling, weer eens uit die dun, kosbare boekie, Chesterton se Orthodoxy: 'But I was frightfully fond of the universe' (Chesterton 1961:62). In my credo-gedig word my opgehewe hande as 't ware deur God van die hemel af weggestoot terug na die aarde toe om te bid dat Hy die aarde nie uit sy hande sal laat val nie:

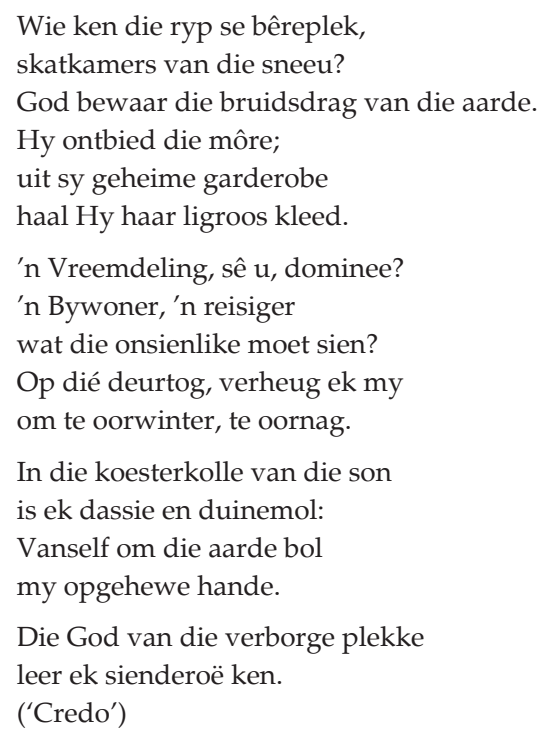

My afwending van die ingesteldheid op die hiernamaals na die hiermaals, het gelei tot belangstelling in die historiese Jesus soos wat hy mens was as Jood in die Israel van sy tyd. Die dogma het dié Jesus op die agtergrond gedwing deur die leerstellige verkondiging van die evangeliese boodskap. Die vraag wat die kerk ná die Holocaust in die hele Europa - nie net in Duitsland nie - moes beantwoord, was hoe so 'n verskriklike menseslagting in sy midde kon plaasvind. Dit het daartoe gelei dat teoloë na Jesus begin kyk het 'met nieuwe ogen' soos C.J. den Heyer (2000:133) met erkenning aan Marcus Borg sê en byvoeg: 'Ik leerde hem zien als met joodse ogen.' Maar Jesus het ook teruggekeer in die werk van Joodse outeurs. Ek is diep aangryp deur wat Den Heyer aanhaal uit die Nederlandse vertaling van 'n roman van die Frans-Joodse skrywer André Scharz-Bart, De laatste der rechtvaardigen (Le Dernier des Justes); in besonder dié sin: 'Het was in het jaar 1933 na de komst van Jezus, wonderschone boodschapper van de onmogelijke liefde' (Den Heyer 2000:137). Dit is wat Jesus vir my geword het soos wat ek sê in my herskrywing van die gekanoniseerde geloofsbelydenis in my bundel Duskant die einders (2004):

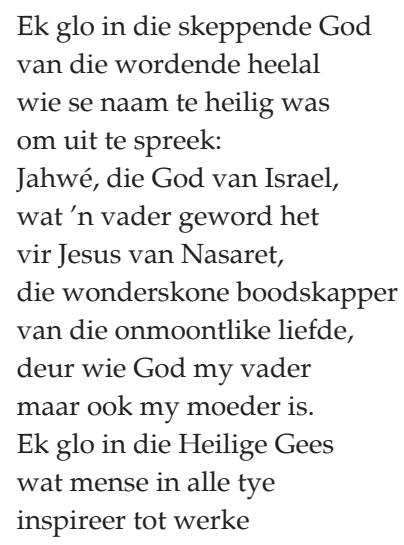


wat die stempel dra

van die ewige.

Ek glo dat omdat ek lewe

ek aan alle lewendes

sorg en deernis verskuldig is

en ek glo dat as ek sterf

ek opgeneem sal word

in die durende siklus

van vernuwing en verval

en dat die lewe triomfeer

in elke geboortekreet

omdat die lewe magtiger is

as die dood.

('Die geloofsbelydenis van 'n afvallige')

Die boek wat my denke oor Jesus beslissend beïnvloed het en van alle teologiese werke die grootste invloed op my poësie gehad het - en nog het - is Andries van Aarde se Fatherless in Galilee: Jesus as child of God. Oor Jesus se Joodsheid sê hy: 'Jesus of Nazareth, etnically an Israelite, crossed bounderies all the way without being "un-Jewish"' (Van Aarde 2001:203). Dit gaan vir Van Aarde oor Jesus se grensoorskryding binne die samelewing as gevolg van sy vaderloosheid. Hy laat die vraag oop of Josef 'n fiktiewe figuur was of om ander redes ná Jesus se geboorte uit sy lewe verdwyn het. Jesus se optredes in die uitleef van sy roeping skryf hy wel onomwonde toe aan die afwesigheid van 'n aardse vader in sy lewe; 'n insig wat ek kon deel en verwoord in my 'geloofsbelydenis' met die verwysing na Jahwé 'wat 'n vader geword het/vir Jesus van Nasaret' (my kursivering). 'n Mens sou die spanning tussen Jesus en sy familie, sy moeder ingesluit, kon toeskryf aan sy oorskryding van grense om die geminagtes in sy samelewing, kinders en alleenstaande vroue, in te sluit waarvoor hulle geen begrip gehad het nie.

Ek het jare lank die begeerte gehad om teen die tradisie van die verheerlikte madonna in die letterkunde en kunste in, ' $n$ gedig te skryf oor die Joodse meisie wat die moeder geword het van Jesus. Dit het Van Aarde vir my moontlik gemaak deur onder andere Schüssler-Fiorenza aan te haal wat in haar boek Jesus - Miriam's Child na Maria verwys as 'the young woman and teenage mother ... probably not more than twelve or thirteen years old, pregnant, frightened and single' (Van Aarde 2001:38). Eybers se suggestie in haar gedig, 'Maria', van 'n buite-egtelike swangerskap wat verantwoordelik is vir die 'bure-agterdog' wat Maria 'pla', kon ek tot sy volle konsekwensies deurvoer in my gedig 'Ontdaan' wat ek opgedra het aan Andries van Aarde.

Ek het Eybers ook nagevolg deur, soos sy, met Maria in gesprek te tree. Om by die historiese Maria uit te kom, moes ek die geboorteverhale ontmitologiseer; hulle 'ontdoen' ('ontneem') van die sfeer waarin die evangeliste, Matteus en Lukas, hulle omhul. In die vierde en vyfde strofe skryf ek in teen die visuele voorstellinge van Maria in die beeldende kunste wat by ons ingeprent is: die swanger meisie met die stralekrans en die blou mantel wat die Saligmaker sal baar en die jong moeder in die kriptoneel:
Nee, jy het nie 'n Fra Angelico-blou mantel gedra en bo jou hoof het geen stralekrans geskyn toe 'n sogenaamde engel jou die boodskap sou gebring het dat die kind wat jy gedra het die Seun van God was nie.

Nee, jy moes donker gewees het van huid en haar - eie aan die volk waartoe jy behoort het en aan die vrug van jou skoot moes jy soos alle uitgeworpenes swaar gedra het; of hy uit ongeoorloofde liefde verwek is of uit geoorloofde misbruik van 'n vrou.

My gedig is kennelik 'n pendant van Eybers se 'Maria' deur die geheime werkinge van die kreatiewe gees. 'Maria' is deel van die Afrikaner se kollektiewe onderbewuste en in die besonder van myne as die groot voorbeeld vir vrouedigters binne die vroulike tradisie. Van my vermenslikte siening van Maria, is ek reëlreg gelei na Jesus soos hy hom in die evangelies bekend maak as leermeester, as die boodskapper van God:

Ek was lank op reis na hom

maar eers toe die engelekore stil geword het

en ek sy stem kon hoor;

eers toe die geur van wierook en mirre verdamp het

en ek die sweet en stof kon ruik

van sy tuistelose omswerwinge,

het ek my rug gedraai op die Kind van Bethlehem

en jou seun ontmoet, rabbi Jesjoea van Nasaret.

Oor Jesus wat my rabbi geword het, skryf Van Aarde (2001):

As a fatherless figure, Jesus saw himself as the protector of fatherless children in Galilee, as well as women who did not 'belong' to a man. These women and children were regarded as outcasts since they fit not into the patriarchal system ... (H)e protected patriarchless women and fatherless children, not from above, but from a position of being one of them. Jesus not only call God 'Father', but also lived among the outcasts as if they were all children of God. (bl. 197)

Reeds in Oorstaanson (1982), my vierde bundel, spreek die gedig 'Da Jesus an dem Kreuze stund' naas etlike gedigte oor die verkondigde Christus ('Pase', 'Kruis', 'Pinkster') van my onkunde oor wie Jesus werklik was en impliseer daarmee my reis na die historiese Jesus: 'Ek het U lief en het U ook verraai/beweer dat ek U, Man van Smarte, ken.' Soos Andries van Aarde hom identifiseer, kon ek Jesus as my rabbi leer ken en verstaan. Hierdie rabbi het my as vrou, en spesifiek as ongetroude vrou, van elke vorm van minderwaardigheid bevry en my toegelaat tot sy dissipelkring en so tot die volheid van lewe. Daardeur kan my vrouwees en my digterskap in harmonie met mekaar bestaan en bevrugtend op mekaar inwerk. In 'n ongepubliseerde vers wens ek 'n geliefde naasbestaande vrou, en implisiet alle vroue, toe om hulle te bevry van die stereotipering wat 'n manlik en godsdienstig georiënteerde kultuur op hulle wil afdwing om van hulle bannelinge in eie samelewing te maak:

Vaderloos

Mark 3:31-35

Ek wonder of ek jou liewer

kon gehad het as wat ek jou het

as ek jou sidderend van pyn 
deur my oopgespalkte bene

in hierdie brokkelrige wêreld ingestoot het?

Ek weet van jou pyn

oor jou kind wat om jou selfbehoud

moet groot word met ' $n$ afwesige vader

wat net oor naweke sy opwagting maak.

Nou wonder ek of dit jou sal troos

as jy die ander Jesus ontmoet

wat ek leer ken het op my lewenspad?

Dié Jesus wat omgegee het vir vrouens sonder man,

geteister deur die konvensies van sy tyd:

Marta en Maria van Betanië

en die Samaritaanse vrou by die put;

almal wat hy wou laat drink van die water

wat die diepste dors van menswees les;

die Joodse rabbi wat ook buite die sinagoge

op ' $n$ heuwel of uit ' $n$ vasgemeerde boot

die Tora se eis om die liefde gepredik het.

Dis daar waar ek glo dat jy hom sal vind

in die vrye natuur,

nie by sy moeder en sy broers

wat hulle eenkant gehou

en morrend laat weet het

dat hulle hom soek nie,

maar te midde van sy luisteraars

in 'n kring om hom geskaar

van wie hy gesê het:

'Hulle is my moeder en my broers en my suster.'

\section{Erkenning}

Ek wil graag my dank uitspreek teenoor Jean Oosthuizen wie se begrip en waardering vir my godsdiensbeskouing en my religieuse gedigte my ondersteun en inspireer.

\section{Mededingende belange}

Die outeur verklaar hiermee dat sy geen finansiële of persoonlike verbintenis het met enige party wat haar voordelig of nadelig in die skryf van hierdie artikel kon beïnvloed nie.

\section{Literatuurverwysings}

Bennet, P., 1986, My life a loaded gun: Dickinson, Plath, Rich and female creativity, University of Illinois Press, Chicago, IL.
Bennet, P., 1990, Emily Dickinson: Woman poet, lowa Press, lowa City, IA.

Chesterton, G.K., 1961, Orthodoxy, Collins Clear Type Press, London.

Clarcke Mossberg, A.B., 1982, When a writer is a daughter, Indiana Universty Press, Bloomington, IN

Cloete, T.T., 1970, Kaneel, Nasionale Boekhandel Bpk., Kaapstad.

Cloete, T.T., 1980, 'Poësie', in T.T. Cloete, Die Afrikaanse literatuur sedert sestig, Nasou, Kaapstad.

Dekker, G., 1961, Afrikaanse literatuurgeskiedenis, Nasionale Boekhandel Bpk., Kaapstad.

Den Heyer, C.J., 2000, Ruim geloven: Een theologisch zelfgesprek, Meinema, Zoetermeer.

Eybers, E., 1966, "n Pastoriedogter', in Herinnering se wei, Perskor, Johannesburg.

Eybers, E., 1978, Voetpad van verkenning, Human \& Rousseau, Kaapstad.

Eybers, E., 1987, Rymdwang, Human \& Rousseau, Kaapstad.

Eybers, E., 1990, Versamelde gedigte, Human \& Rousseau, Kaapstad.

Eybers, E., 2005, Valreep/Stirrup-cup, Human \& Rousseau, Kaapstad.

Grobler, P. du P., 1962, Verkenning, Human \& Rousseau, Kaapstad.

Grové, A.P., 1958, Oordeel en vooroordeel, Nasionale Boekhandel, Kaapstad.

Homans, M., 1980, Women writers and poetic identity, University Press, Princeton, NJ.

Jansen, E., 1996, Afstand en verbintenis: Elisabeth Eybers in Amsterdam, J.L. van Schaik, Pretoria.

Kannemeyer, J. C., 2005, Die Afrikaanse literatuur 1652-2004, Human \& Rousseau, Kaapstad.

Malherbe, F.E.J., 1958, Afrikaanse lewe en letterkunde, Universiteituitgewers en Boekhandelaars, Stellenbosch en Grahamstad.

Martin, W., 2011, Groot woordeboek. Afrikaans en Nederlands (ANNA), Pharos, Kaapstad.

Meijer, M., 1988, De lust tot lezen: Nederlandse dichteressen en het literaire systeem, Van Gennep, Amsterdam.

Odendaal, F.F. \& Gouws R.H., 2005, Handwoordeboek van die Afrikaanse taal (HAT), Pearson Education South Africa, Pinelands.

Opperman, D.J., Digters van Dertig, 1962, Nasionale Boekhandel, Kaapstad.

Paglia, C., 1992, Sex, art, and American culture, Vintage Books, New York, NY.

Potok, C., 1967, The chosen, Simon and Schuster, New York, NY.

Potok, C., 1972, My name is Asher Lev, Random House, New York, NY.

Rosten, L., 1976, The joys of Yiddish, Penguin Books, London.

Spies, L. ,1971, Digby Vergenoeg, Human \& Rousseau, Kaapstad.

Spies, L., 1973, Winterhawe, Human \& Rousseau, Kaapstad.

Spies, L., 1976, Dagreis, Human \& Rousseau, Kaapstad.

Spies, L., 1992, Hiermaals, Human \& Rousseau, Kaapstad.

Spies, L., 1995, Die enkel taak: Die merkwaardige verwantskap tussen Elisabeth Eybers en Emily Dickinson, Queillerie, Kaapstad.

Spies, L., 1998, 'Elisabeth Eybers', in H.P. van Coller (red.), Perspektief en profiel, deel 1, J.L. van Schaik, Pretoria.

Spies, L., 1999, Sy sien webbe roer: 'n Keuse uit die werk van Afrikaanse digteresse Human \& Rousseau, Kaapstad.

Spies, L., 2004, Duskant die einders, Human \& Rousseau, Kaapstad

Spies, L., 2006, 'Die poësie van Elisabeth Eybers: 'n Digterskap van sewentig jaar', Tydskrif vir Letterkunde 43(2), 13-30.

Spies, L., 2010, Tydelose gety, Protea Boekhuis, Pretoria

Van Aarde, A.G., 2001, Fatherless in Galilee: Jesus as Child of God, Trinity Press International, Harrisburg, PA. 